\title{
新热术ルフィリン誘導体の合成と性質
}

\author{
阪田功、中島進 ${ }^{1}$ 、竹村践 ${ }^{2}$ \\ 東洋薄荷工業(株)、1旭川医科大学手術部、“北海道大学雷子科学磁究所
}

\author{
Synthesis and Properties of New Porphyrin Derivatives \\ Is ao Sakata, Susumu Nakajima ${ }^{1}$, Takeshi Takemura ${ }^{2}$
}

Toyo Hakka Kogyo Co.,Ltd.,

${ }^{1}$ Division of Surgical Operation, Asahikawa Medical College

${ }^{2}$ Research Institute for Electronic Science, Hokkaido University

\begin{abstract}
A series of alkyl ether based on Ga porphyrin bisaspartic acid are prepared. Relationship tumor tissue affinity ith cherical structure of these Ga complexes have investigated by means of Rt. at HPLC, biodistribution on $N_{2}$-PLS method and HPLC analysis , and interaction with proteins (HSA, LDL, HDL, transferrin). The decyl ether $(n=10)$ -bearing Ga complex is one of the most efficient sensitizers on tumor tissue affinity. The corresponding Hn analogue are also similar to Ga complex. Based on these results, we are synthesized porphyrin derivatives shown Scheme 1.
\end{abstract}

1. 腥言

ホルフィリン誘学体が医撩用にと䊅介されて 以来、记線力学的治潦法 [Photodynamic Therapy(PDT)]は最近䈏に盛んになってきた。 增感戍の赫度向上や新規骨格を有するボルフ ィリン誘導体の合成研觉者ならびにこれらを医 嶙店用へと開発する臨床家が增えていることは

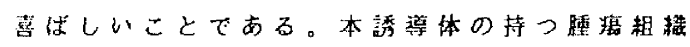
高彩和性户何が起こるか想像つかない神秘性が 、我々を含めた多くの研究者を㴔にしているの であろう。我々はボルフィリンがなぜ虞に取り

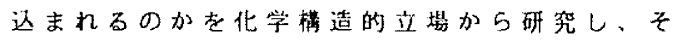
の耛果を踏まえてより僈れたボルフィリン誘導 体を社会に提基す石ことを目的として、1 0 数 年来より基磁研受比り耝んてきた。そして数 々の新しい知見を得たが、ここでもう一度振り 返ってボルフィリン誘導体の俞成の現桨と将来 について述ベてみたい。

\section{2. 現状}

合成原料としてボルフィりン類を考える埸合 Fig. 1 に示す 4 種の基本筲格を先ず思い浮べる 必要がある。Fig.10上段が正式化学棈造、 


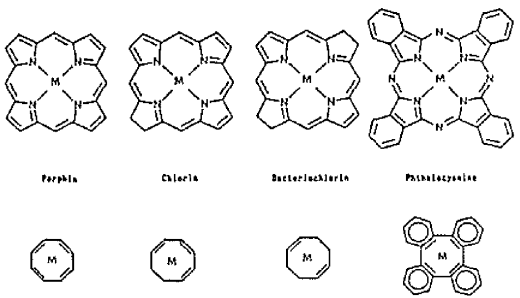

Fig. 1

Structure of Porphyrins and Related Compounds

下段がその特徵だけを捉えた略式構造式を示す 。これらの詳䋖な説明は以前の本誌論文に記载 しているのてこここで割受する。これまで PDT 用の光增感刘としてHPD、DHE主成分のPhot of rin II .TPPS. $2 n-P C S_{4} 、 P H 1126$ などが合成提供 されてきた。そして最近新たに、我々が開発し た新規クロリン誘碂体である NPe 6、BPD、ALAが登埸した。その略式構造式を Fig. 2 に示す。Photofrin I とTPPSは血色秦と 同じポルフィリン筒格を持方最長波長吸收湍が $630 \mathrm{n}$ 円でる。一方、Zn-PCS。は碩料てあるつ

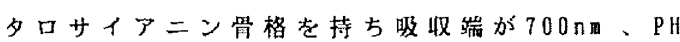
1126 NPe 6 は葉录素と同U゙クロリン骨格を持 ち吸收端が650n田である。他方、BPDと新嫢開

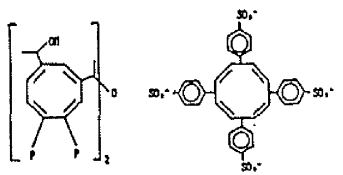

Phototrin II

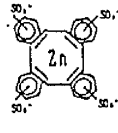

$2 n-p C S$

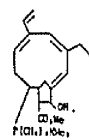

$P H-1126$

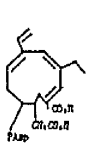

NPe 6

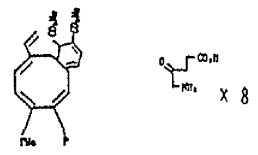

ALA

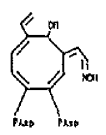

ATX-\$10
発ATX-S10 は合成出発原料として血色素由来の ボルフィリンを用いているが合成途中でクロリ

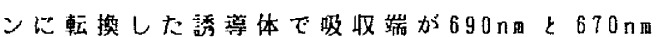
であり、またALAはウロボルフィリンを䎦てプ ロトボフィリンに生合成される前駆体であり 面白い試みが進行している。

3. 過程

基本的なことを解決するために、我々は先ず 最初に血色秦由来のボルフィンおよび䔉录泰由 来のフォルビン（広義にはクロリン）新導体あ るいはそれらの金属错体の合成を試みた。得ら れた誘蒠体を用いて担癌八ムスタ一および表面

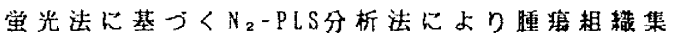
䆏性の粠造活性相関を模討した。その拮果を Fig. 3 に示す。親油基を担持したボルフィンの 場合と多数の親水基を担っているフォルピンの 埸合が高活性を示した。またこれらをそれぞれ 金属錯体とした場合には、以上の哧果とはすべ て逆の関保を呈した。また二量体構造は一般的 に良好であった。

Fig. 3 Relationstip batwor sidechoin of porphyrins

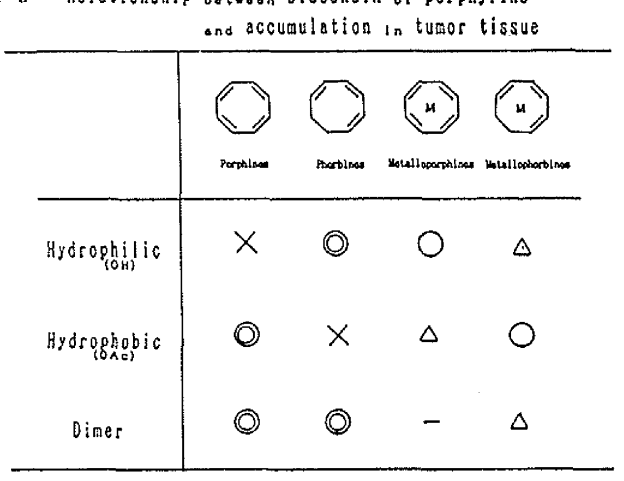

これらの哧果から、漞水基を多く担持した血

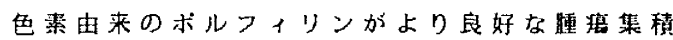
性を示すと示唆されたので、出発原料としてプ ロトボルフィリンジメルエステルを用い側鎖 岑素数の珙なるGaボルフィリンアスバラギン 酸誘導体を合成し(Schene 1)，更に羢細な構 
造活性相関を㛟討した。台成した 11 種のG $\mathrm{G}$ 錯体を用いて H P L C 分析に上る保持時間 (Ret ention Time, Rt.) な 5 びにオク夕ノールー水 系による分配倸数を求め、睡㾂粗溗集積性との 関係を簡便に類推できるようにした。ついで胆 管癌移植八ムスターおよびColon 26 移植 CDF 1 マ ウスを用いて表面蛍光法（N２－PLS法）による $\mathrm{G} \mathrm{a}$ 錯体の生体内分布を分析し、Fig.4 以示す 結果を得た。㑡鎖炭素数(n)の增加に伴って

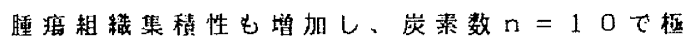
大に達し以下诚少した。一方、睡瘦耝精集積性 の目安となるアルブミン(HSA) との相互作用を $\mathrm{G} a$ 錯体の可視吸収スペクトルより測定したと ころ、 $\mathrm{n}=10$ て見掛けの平衡定数 $($ 凡)最も 高く、先の生体内分布と同㥞の耛果が見られた

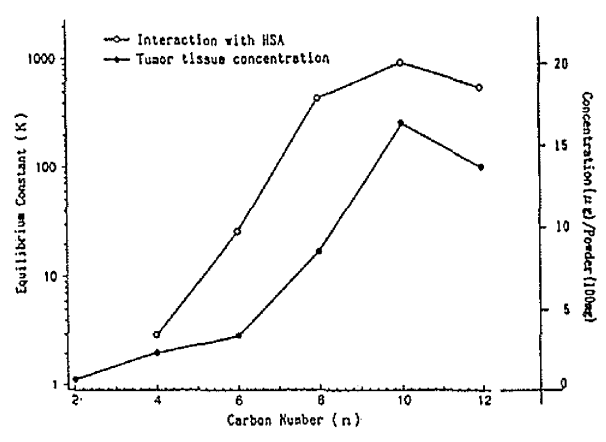

Fig. 5 Turor Tissue Concentration and Interaction rith ilLs of Go Porphtirins

他方、生体内分布党光法だけでなくアセト ンバウダー法によって $G$ a錯体の䁾器抽出艺行

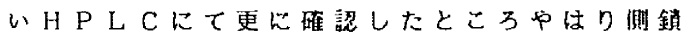
の炭素数 $n=10$ 㽞も多く集積し他の䊅果と む一致していた。その結果をFig. 5 に示す。

また、G a錯体と種々の血清りボタンバク筫 、すなわちHSA、LDL、HDL、トランスフォリン(TRF) との相 互作用を吸収スペクトルにて蚞討したところ、 やはり側顉炭素数几の增加と共に親和性を增し 、几ニュ○で最大になっていることが判った。

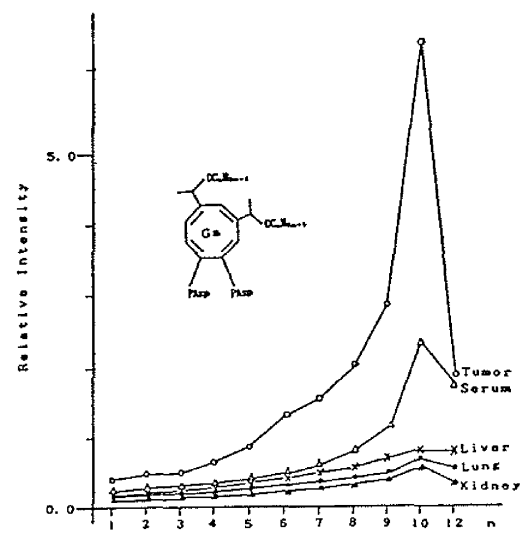

Fig. 4 Biodistribution of Ga Porphysins oy N.-PLS (Fig.6)なお、これらタンバク筫のうち HDL に对するボルフィリンの平衡定数 K 値はnの数 にかかわらずほとんどー定であった。したがっ て新水性の高いボルフィリン誘酎体はHSAやし しとの親和性に比べてHDLに良い親和性を示す と思われた。

Mnアナログ錯体も同桹以11種合成し、H P L C 分析によるRt。なび生体内分不、お よびHSAとの相互作用を㛟討し、G $\mathrm{G}$ 錯体と比 㜞した。Mn錯体においては側镍炭策数 $n=$ 12 でより强い活性が認められたが、両者とも 酷似していた。この事実は後に種々の誘票体を 合成する上で非常に示唆に舅んでいた。なお無 金尾アナログ体の場合には側銿炭素数 $n=6$ が 最良であった。 4. 摆来

以上の知見を考えあわせて、新たなる睡塞耝 轿集皘性ボルフィリン誘導体の合成を進めた。 そのルートをSchemelに示す。今後これ5の梁 剂が癌の診断・治磨に没立つ化合物の走りとな ることを願う。 

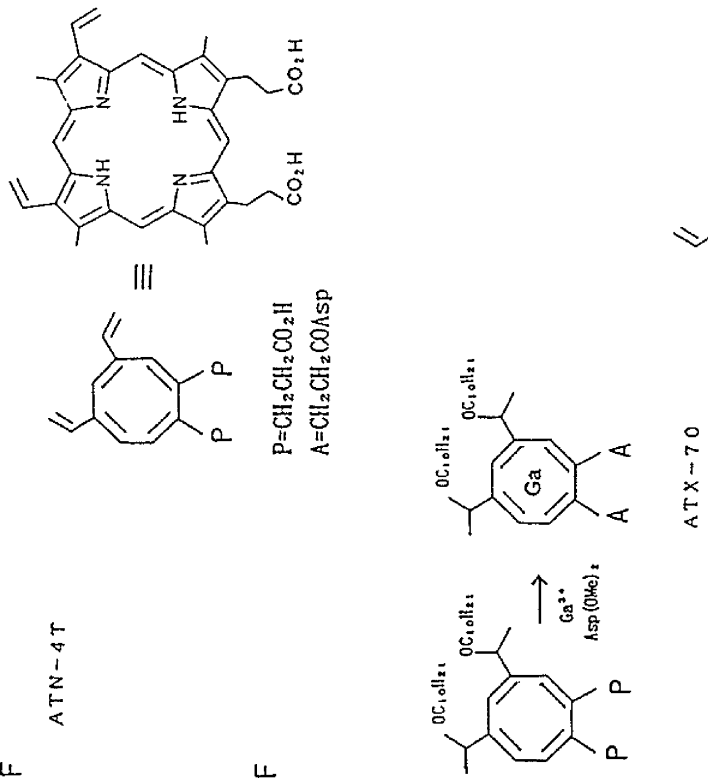
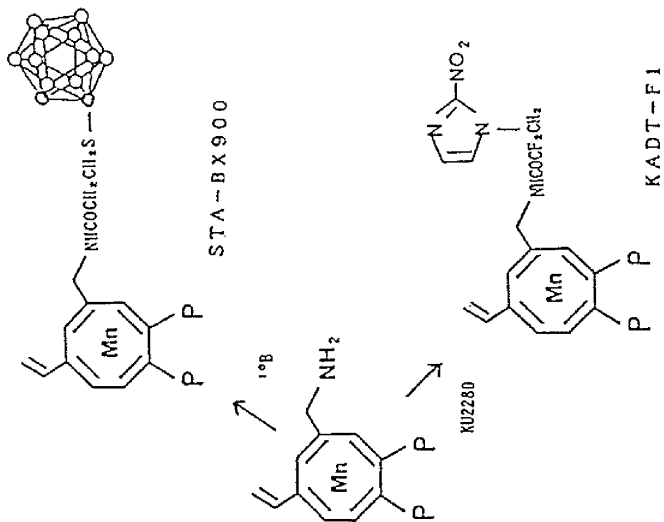

定 $\uparrow:$<smiles>[CH]OC1=C([Hg])C=CC=CC=C1</smiles>

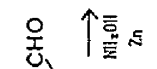<smiles>C=CC1=CC=C(C)C(C)=CC(C)=C1</smiles>

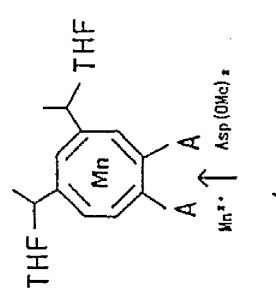<smiles>C#CC(C)C1=CC(C)=CC(C)=CC1C</smiles>

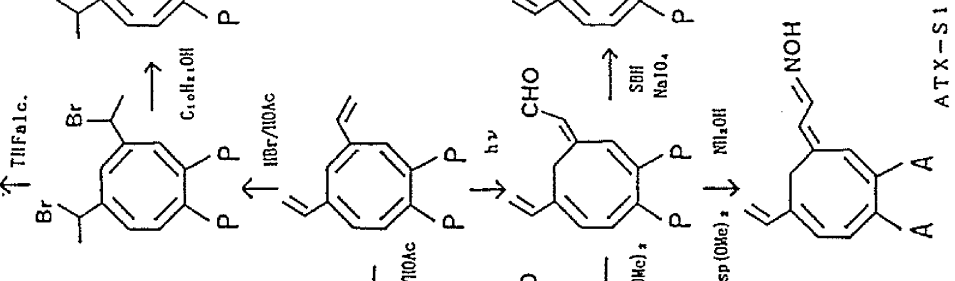

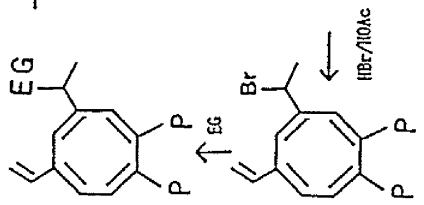<smiles>C=C1C=C=C(C)C(C)=CC(CO)C1</smiles>
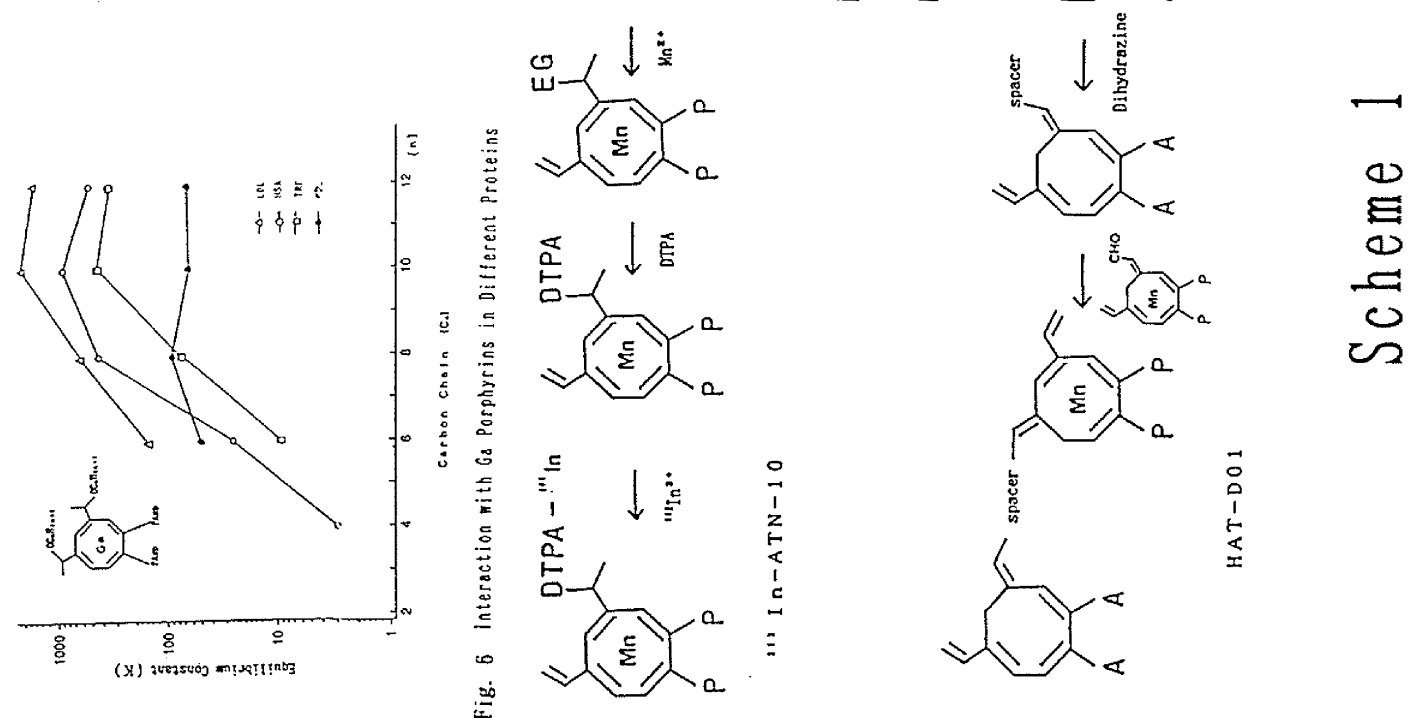